TecnoLógicas

ISSN-p 0123-7799

ISSN-e 2256-5337

Vol. 22, No. 46, pp 15-23

Sep-dic de 2019

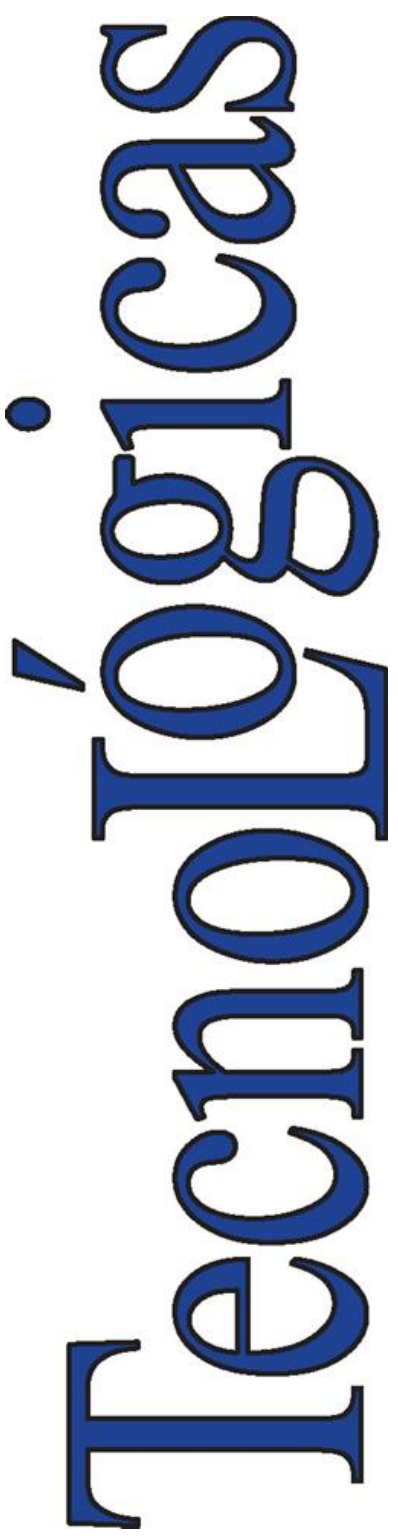

(C) Instituto Tecnológico Metropolitano Este trabajo está licenciado bajo una Licencia Internacional Creative Commons Atribución (CC BY-NC-SA)

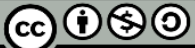

Artículo de Investigación/ Research Article

\section{Grinding methods effects on the synthesis of Potassium-Sodium Niobate powders by oxide mixing}

\section{Efectos de los métodos de molienda en la síntesis de polvos de Niobato de Sodio y Potasio por mezcla de óxidos}

\author{
María C. Quintero(D)1, Miryam Rincón (D)2, Jorge M. \\ Osorio-Guillén (D) 3 , Diana López ${ }^{4}{ }^{4}$ y \\ Fernando A. Londoño(D)
}

Recibido: 14 de marzo de 2019

Aceptado: 08 de agosto de 2019

Cómo citar / How to cite

M. C. Quintero, M. Rincón, J. M. Osorio-Guillén, D. López y F. A. Londoño, "Grinding methods effects on the synthesis of Potassium Sodium Niobate powders by oxide mixing”, TecnoLógicas, vol. 22, no. 46, pp. 15-23, 2019. https://doi.org/10.22430/22565337.1269

1 Ing. Química, Grupo de Estado sólido, Instituto de física, Universidad de Antioquia, Medellín-Colombia, mariaclara3010@gmail.com

2 PhD. en Ciencia, Departamento de Física, Universidad de Nacional de Colombia, Bogotá-Colombia, mrinconj@unal.edu.co

3 PhD. en Física, Grupo de Estado sólido, Instituto de física, Universidad de Antioquia, Medellín-Colombia, mario.osorio@udea.edu.co

4 PhD. en Química, Química de Recursos Energéticos y Medio Ambiente, Universidad de Antioquia, Medellín-Colombia, dplope@gmail.com

5 PhD. en Ciencias, Grupo de Instrumentación científica y microelectrónica, Universidad de Antioquia, Medellín-Colombia, fernandoa.londono@udea.edu.co 


\section{Abstract}

Piezoelectric materials are widely used in electronic devices and, traditionally, various lead-based materials have been implemented in such applications. However, because of the damage caused by lead, other materials with similar characteristics that do not cause a negative impact on human health and the environment have been developed. A material with those characteristics is potassium-sodium niobite, $\mathrm{K}_{0.5} \mathrm{Na}_{0.5} \mathrm{NbO}_{3}$. In this study, we investigate the thermogravimetric, structural, and microstructural properties of powders of such system obtained through oxide mixing with the aim of establishing the effect and efficiency of grinding (using a horizontal and a planetary ball mill grinder) on the production of the final material. It was determined that horizontal grinding and calcination at $900^{\circ} \mathrm{C}$ create the optimal conditions for obtaining $\mathrm{K}_{0.5} \mathrm{Na}_{0.5} \mathrm{NbO}_{3}$ powders, by oxide mixing, with the adequate structure and microstructure to continue the densification and/or doping processes.

\section{Keywords}

Potassium-sodium Niobate, oxide mixture, lead-free.

\section{Resumen}

Los materiales piezoeléctricos son ampliamente utilizados en dispositivos electrónicos. Tradicionalmente, para tales aplicaciones, se han utilizado diversos materiales a base de plomo; sin embargo, debido al daño causado por este elemento, se han desarrollado materias primas con características similares que no causen un impacto negativo a la sociedad o al medio ambiente. Un material con estas características es el niobato de potasio y sodio, $K_{0.5} \mathrm{Na}_{0.5} \mathrm{NbO}_{3}$. En este artículo, se realizaron análisis termogravimétricos, estructurales y microestructurales para los polvos del sistema $K_{0.5} \mathrm{Na}_{0.5} \mathrm{NbO}_{3}$ obtenidos mediante mezcla de óxido, con el objetivo de determinar el efecto y la eficiencia de la molienda utilizando molinos de bolas, planetario y horizontal en la etapa de mezcla de los reactivos, para la producción del polvo final. Se determinó que el uso de la molienda horizontal y la calcinación a $900{ }^{\circ} \mathrm{C}$ crean las condiciones óptimas para obtener polvos $\mathrm{K}_{0.5} \mathrm{Na}_{0.5} \mathrm{NbO}_{3}$ con una estructura y microestructura adecuadas para continuar los procesos de densificación y/o dopaje.

\section{Palabras clave}

Niobato de sodio y potasio, mezcla de óxidos, libre de plomo. 


\section{INTRODUCTION}

Piezoelectric materials are very important for the electro-electronic industry; they are used in ultrasound devices, electro-mechanical energy converters, and clean energy generators. However, some of the main components of such materials are elements that cause human health problems and environmental damage. For instance, lead zirconate titanate (PZT), one of the most commercially used piezoelectric materials, contains around $60 \%$ lead by weight [1]. People who suffer from lead poisoning can experience headaches, constipation, nausea, anemia, and reduced fertility. Moreover, prolonged exposure to lead can cause more serious symptoms, such as severe damage to nerves, kidneys, and brain [2]. Consequently, we must find possible lead substitutes. A promising candidate to replace $\mathrm{PZT}$ is sodium potassium niobate $\left((\mathrm{K}, \mathrm{Na}) \mathrm{NbO}_{3}, \mathrm{KNN}\right)$, a ceramic material that possesses excellent piezoelectric properties [3][4]. Further, said ceramic host might be doped with rare earth ions, transforming KNN into a multifunctional ceramic with two or more desirable properties, e.g., piezoelectricity and photoluminescence, which make it suitable for manufacturing sensors and actuators [5]. However, the production of $K_{0.5} \mathrm{Na}_{0.5} \mathrm{NbO}_{3}$ involves many difficult conditions that include the volatility of alkaline elements, the high influence of stoichiometry on the physical properties, and problems with densification processes [6], [7].

KNN production by means of solid-state synthesis requires several hours of reaction and high temperatures, which hampers said production due to the instability of the precursors and the volatility of alkaline metals [5]. In order to solve the densification problem, different advanced processes have been used to promote sintering, such as spark plasma sintering [8] and hot pressing [9].
In spite of those disadvantages, different factors that affect the obtained powders-such as the selection of precursors, the chemical heterogeneity of calcined powder, calcination temperatures, and grain size are still studied and investigated in full detail [7], [10], [11], [12].

The fragmentation mechanism of micrometer particles induced by the grinding process may be a key element to obtain one or another particle shape of micrometric size [13]. This is very important to obtain $\mathrm{K}_{0.5} \mathrm{Na}_{0.5} \mathrm{NbO}_{3}$ powders with structural and microstructural properties that allow the continuation of the densification process.

This work presents a comparison and optimization of different conditions to prepare ceramic powders of $K_{0.5} \mathrm{Na}_{0.5} \mathrm{NbO}_{3}$ in order to determine the effect and efficiency of using a horizontal grinder and a planetary ball mill grinder. Such powders were obtained by the solid-state reaction method, which offers several advantages over the techniques mentioned above, e.g., a simple synthesis route, low synthesis cost, and ease of commercial application [14][15][16]. We also studied the reaction conditions that do not alter the elemental composition; additionally, we obtained the specific morphologies, uniform particle sizes, and crystalline phases, which allow the densification and/or doping of the obtained powders.

\section{MATERIALS AND METHODS}

Ceramic powders of $\mathrm{K}_{0.5} \mathrm{Na}_{0.5} \mathrm{NbO}_{3}$ were prepared via solid-state reaction (oxide mixing) using niobium pentoxide, $\mathrm{Nb}_{2} \mathrm{O}_{5}$ (Aldrich, purity 99\%); sodium carbonate, $\mathrm{Na}_{2} \mathrm{CO}_{3}$ (Aldrich, purity 99\%); and potassium carbonate, $\mathrm{K}_{2} \mathrm{CO}_{3}$ (Alfa Aesar, purity 99\%). The powders were mixed according to the stoichiometric formula (1) and calcined according to the diagram in Fig. 1. 


$$
\mathrm{K}_{2} \mathrm{CO}_{3}+\mathrm{Na}_{2} \mathrm{CO}_{3}+2 \mathrm{Nb}_{2} \mathrm{O}_{5} \rightarrow 4 \mathrm{~K}_{0.5} \mathrm{Na}_{0.5} \mathrm{NbO}_{3}+2 \mathrm{CO}_{2}
$$

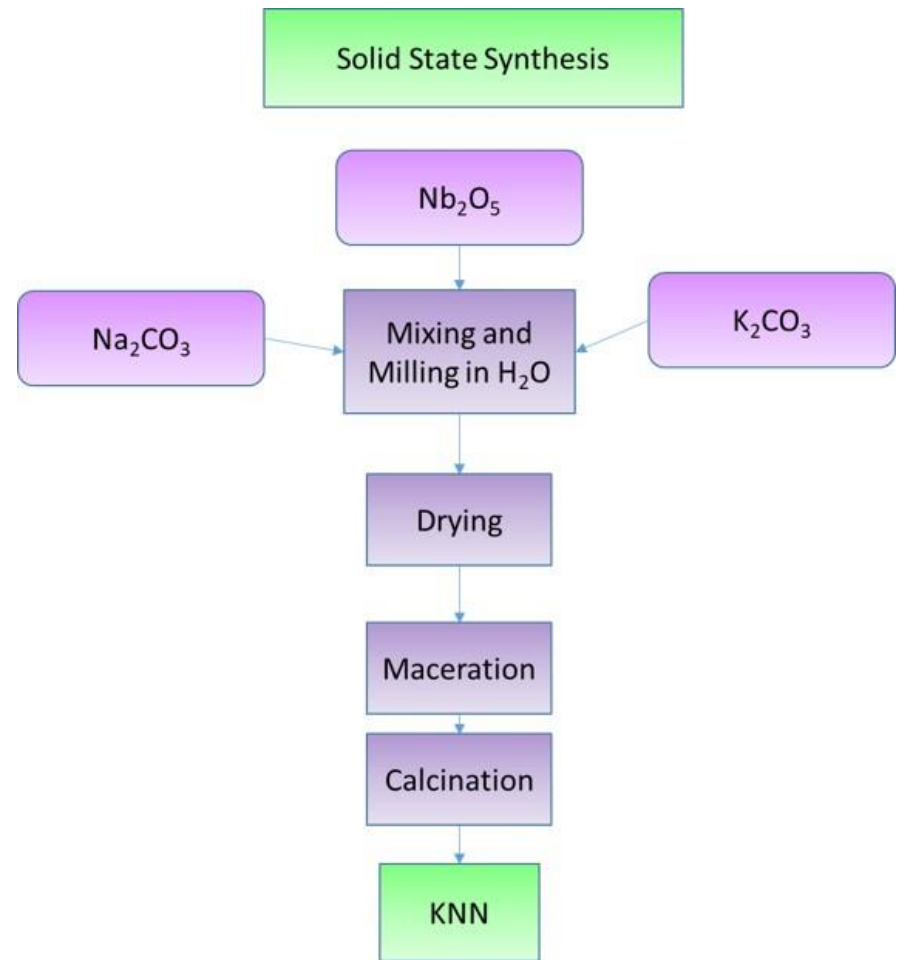

Fig. 1. (Color online) Sequence diagram of the synthesis of KNN in the solid state. Source: Authors' own work.

Initially, each reagent was macerated and thermally treated separately for two hours at $250^{\circ} \mathrm{C}$. This happened because the hygroscopic nature of the carbonates from alkaline metal precursors to eliminate water and guarantee the weight of the powders. Then, the carbonates and the oxide were mixed in two different grinders: a planetary ball mill grinder and a horizontal grinder. The horizontal grinder consists in a cylindrical chamber that contains balls and rotates around its horizontal axis. Balls are swept along by the wall and then fall onto the load. Subsequently, particle fragmentation results from the compression of the particles on the bed by the balls. In the planetary ball mill grinder (PM400 Retsch), the grinding chamber rotates on an orbit around the center. This rotational movement is the self-rotation of the grinding container superimposed. The resulting centrifugal and acting acceleration forces lead to strong grinding effects. Furthermore, there are forces working according to the coriolis acceleration. The result is an intensive grinding effect between the grinding balls and the sample.

The grinding process was carried out for $2 \mathrm{~h}$ at 200 RPM. Afterward, the resulting samples were dried at $110^{\circ} \mathrm{C}$ for $48 \mathrm{~h}$ to remove water and obtain dry ceramic powder for characterization. The reaction sequence of the powders was investigated through thermogravimetry and differential scanning calorimetry (TG and DSC, respectively) at an incremental rate of $10^{\circ} \mathrm{C} / \mathrm{min}$, starting at room temperature and up to $1200^{\circ} \mathrm{C}$, in an air atmosphere, using a Netzsch Simultaneous Thermal Analysis system (STA 409 ET). Such analysis allowed us to establish $800^{\circ} \mathrm{C}, 850^{\circ} \mathrm{C}$, and $900^{\circ} \mathrm{C}$ as the calcination 
temperatures. The phase formation of the calcined samples was identified via x-ray diffraction, with a scan from $\theta=10^{\circ}$ to $\theta=60^{\circ}$, using a Rigaku diffractometer with $\mathrm{CuKa}$ radiation at room temperature. The size, agglomerate formation, and morphology of the particles of the calcined powders were studied via scanning electron microscopy using a Jeol JSM 5800 LV microscope.

\section{RESULTS AND DISCUSSIONS}

Figure 2 shows the TG/DSC of the noncalcined powders of the material obtained after drying and maceration in the horizontal grinder (the TG/DSC results of the powder obtained in the planetary grinder exhibited a similar behavior, but they are not included here). With respect to weight loss, two regions can be clearly distinguished. The first one is a $15.1 \%$ weight loss that can be attributed to water evaporation. The presence of water in the carbonate-oxide powder mixture is due to the hygroscopic nature of both carbonates, particularly $\mathrm{K}_{2} \mathrm{CO}_{3}$, which easily absorbs in a normal atmosphere where the manipulation of the precursor powder takes place. The second region begins at around $850^{\circ} \mathrm{C}$, and it is possibly caused by the loss of carbon dioxide (see products of Equation (1)). These results allow us to establish that, for this work, $800^{\circ} \mathrm{C}, 850^{\circ} \mathrm{C}$, and $900^{\circ} \mathrm{C}$ are the calcination temperatures, which are usually employed for the calcination of $\mathrm{K}_{0.5} \mathrm{Na}_{0.5} \mathrm{NbO}_{3}$ powders obtained by oxide mixing [17].

Figure 3 presents the x-ray diffraction patterns of $\mathrm{K}_{0.5} \mathrm{Na}_{0.5} \mathrm{NbO}_{3}$ powders mixed in a planetary ball mill grinder at $200 \mathrm{RPM}$ for $2 \mathrm{~h}$ and calcined at different temperatures $\left(800^{\circ} \mathrm{C}, 850^{\circ} \mathrm{C}\right.$, and $900^{\circ} \mathrm{C}$ ) for $2 \mathrm{~h}$. At the three temperatures, the expected peaks of $\mathrm{K}_{0.5} \mathrm{Na}_{0.5} \mathrm{NbO}_{3}$ can be seen (PDF card \#32-0822), but with the presence of secondary phases and precursors that do not completely react $\left(\mathrm{K}_{2} \mathrm{CO}_{3}, \mathrm{Nb}_{2} \mathrm{O}_{5}\right.$, and $\left.\mathrm{K}_{3} \mathrm{Nb}_{6} \mathrm{O}_{17}\right)$, as reported by Mahdi et al. [18].

Note that, in the case of the powders produced with the planetary ball mill grinder, the spectrum with the least percentage of secondary phases was obtained calcinating at $850^{\circ} \mathrm{C}$. Characteristic peaks of the $\mathrm{K}_{0.5} \mathrm{Na}_{0.5} \mathrm{NbO}_{3}$ phase can clearly be seen at $2 \theta=45-47$, revealed by the relative intensities at the (200) and (002) diffraction peaks, and $2 \theta=51-53$, which indicate a coexistence of tetragonal and orthorhombic phases of the perovskite structure[19][20].

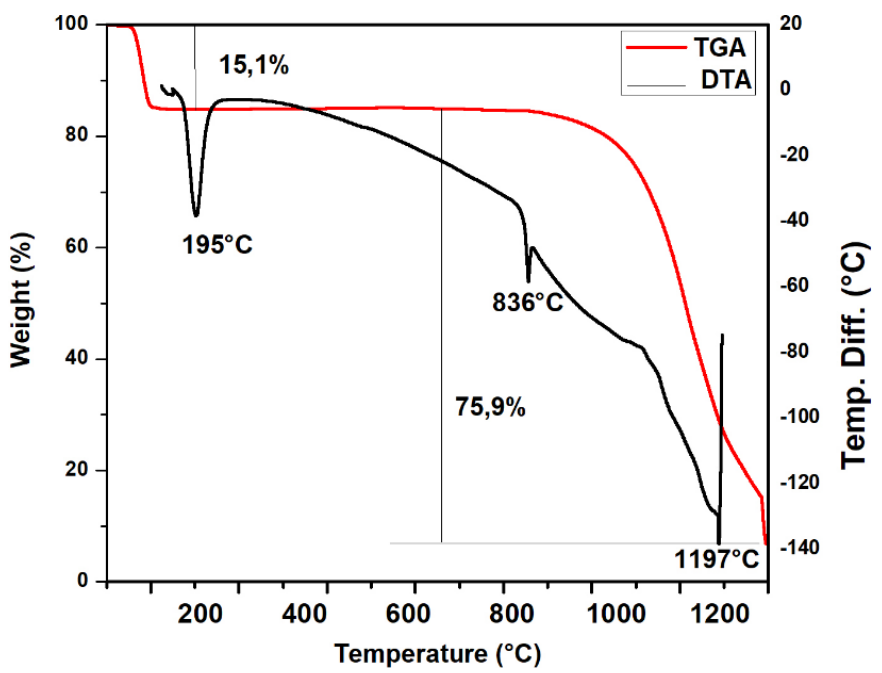

Fig. 2. (Color online) TG/DSC of non-calcined powders obtained by horizontal grinding. Source: Authors' own work. 


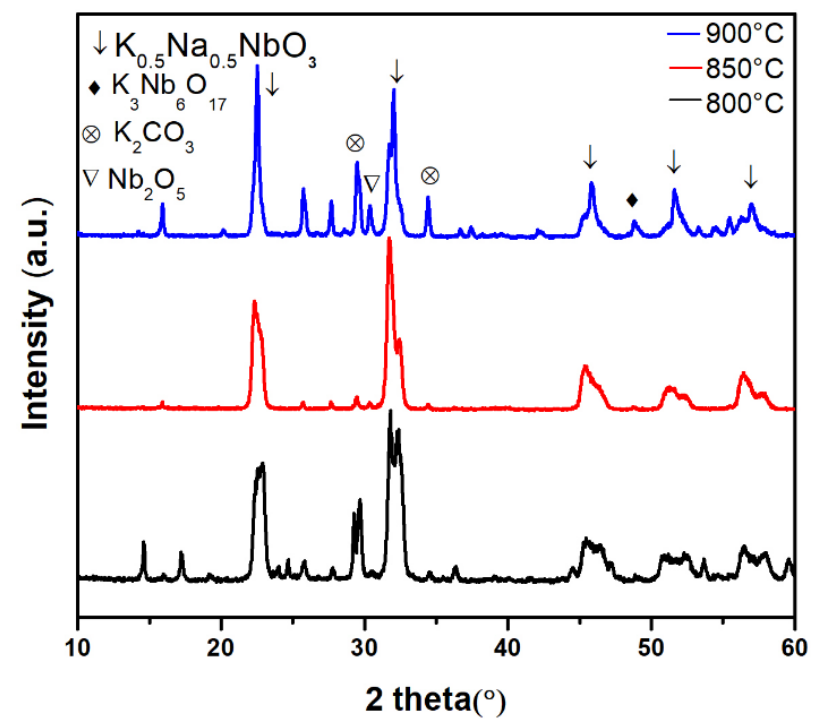

Fig. 3. (Color online) X-ray diffraction pattern of $\mathrm{K}_{0.5} \mathrm{Na}_{0.5} \mathrm{NbO}_{3}$ using a planetary ball mill grinder at different calcination temperatures $\left(800^{\circ} \mathrm{C}, 850^{\circ} \mathrm{C}\right.$, and $\left.900^{\circ} \mathrm{C}\right)$. Source: Authors' own work.

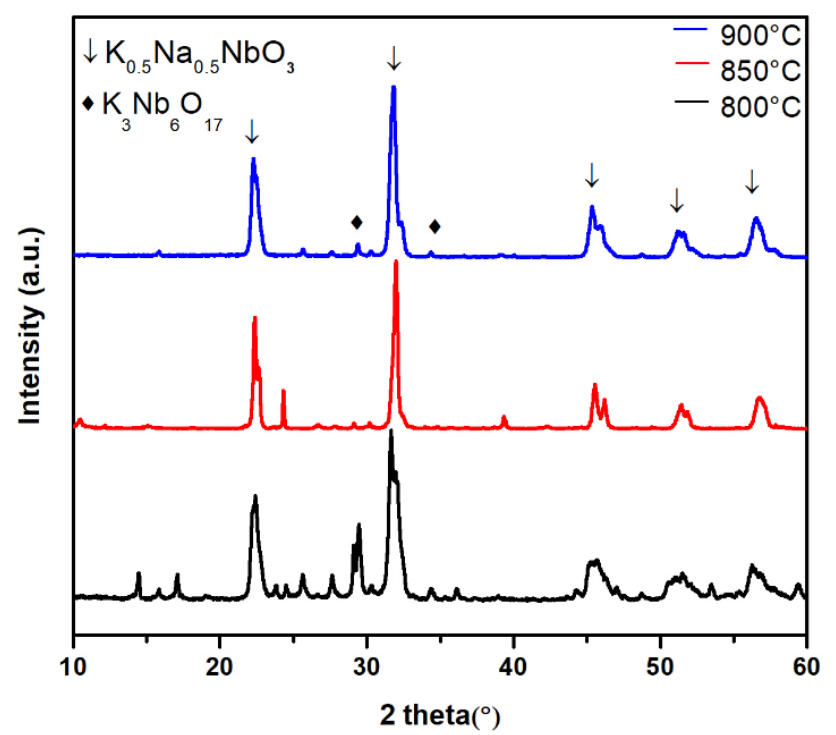

Fig. 4. (Color online) X-ray diffraction pattern of $\mathrm{K}_{0.5} \mathrm{Na}_{0.5} \mathrm{NbO}_{3}$ using a horizontal grinder at different calcination temperatures. Source: Authors' own work.

The x-ray diffraction patterns of calcined powders obtained by horizontal grinding at $800^{\circ} \mathrm{C}, 850^{\circ} \mathrm{C}$, and $900^{\circ} \mathrm{C}$ for $2 \mathrm{~h}$ can be seen in Fig. 4 . As in the case of the powders obtained in the planetary ball mill grinder, the characteristic peaks of $\mathrm{K}_{0.5} \mathrm{Na}_{0.5} \mathrm{NbO}_{3}$ can also be identified. Additionally, the powders in Fig. 4 exhibit a lower percentage of secondary phases than those in Fig. 3 (the secondary phases of $\mathrm{Nb}_{2} \mathrm{O}_{5}$, and $\mathrm{K}_{3} \mathrm{Nb}_{6} \mathrm{O}_{17}$ can be located in Fig. 4). It is also clear that calcined powder obtained by horizontal grinding at $900^{\circ} \mathrm{C}$ for $2 \mathrm{~h}$ is the most suitable option to be calcined and/or doped because it presents a lower quantity of secondary phases. It has been reported that the doping process decreases and/or eliminates the formation of secondary phases in the $\mathrm{K}_{0.5} \mathrm{Na}_{0.5} \mathrm{NbO}_{3}$ system.

Fig. 5 shows the micrographs of the two calcined KNN powders: (a) ground in a planetary ball mill grinder and calcined at $900^{\circ} \mathrm{C}$ and (b) horizontally ground and 
calcined at $900^{\circ} \mathrm{C}$ for $2 \mathrm{~h}$. The micrographs of the powders obtained with the other calcination temperatures are not shown here because of the presence of multiple secondary phases. Parallelepipeds and other cubic morphologies can be seen in Fig. 5, as well as fractured particles and the formation of agglomerates. At said calcination temperature $\left(900^{\circ} \mathrm{C}\right)$, the horizontal grinder produces better results than those reported in the literaturehomogeneous particle sizes $(1-5 \mu \mathrm{m})$, lower formation of agglomerates, and fewer secondary phases-which can be confirmed with the diffractograms [21].

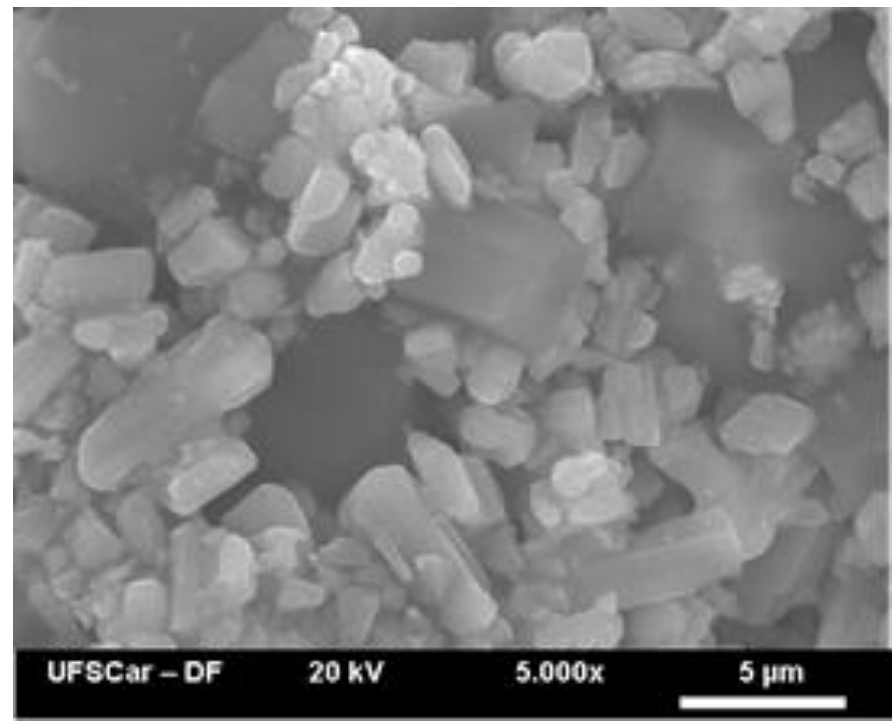

(a) Planetary Ball Mill

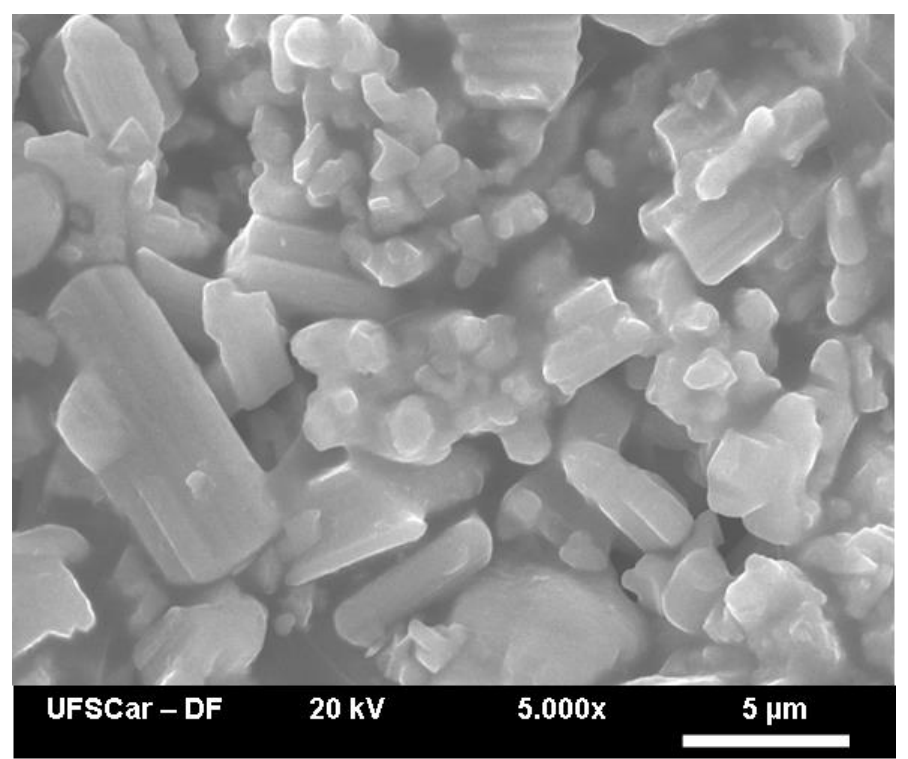

(b) Horizontal Ball Mill

Fig. 5. (Color online) Micrographs of $\mathrm{K}_{0.5} \mathrm{Na}_{0.5} \mathrm{NbO}_{3}$ powders calcined at $900^{\circ} \mathrm{C}$ a) ground in a planetary ball mill grinder and b) horizontally ground. Source: Authors' own work. 


\section{CONCLUSIONS}

The horizontal grinding system enabled us to obtain, by solid-state reaction, powders of the $K_{0.5} \mathrm{Na}_{0.5} \mathrm{NbO}_{3}$ system with a lower percentage of secondary phases and particle size, as well as a morphology suitable for the fabrication of piezoelectric ceramics with KNN and/or doping the powders for the synthesis of multifunctional systems.

\section{ACKNOWLEDGMENTS}

We would like to thank Universidad de Federal de São Carlos in Brazil, Universidad Nacional de Colombia in Bogotá, and CODI Project 2018-23278 of Universidad de Antioquia in Medellín, Colombia.

\section{REFERENCES}

[1] J.-F. Li, K. Wang, F.-Y. Zhu, L.-Q. Cheng, and F.-Z. Yao, "(K,Na)NbO 3 -Based LeadFree Piezoceramics: Fundamental Aspects, Processing Technologies, and Remaining Challenges," J. Am. Ceram. Soc., vol. 96, no. 12, pp. 3677-3696, Dec. 2013. https://doi.org/10.1111/jace. 12715

[2] G. H. Khorrami, A. Kompany, and A. Khorsand Zak, "Structural and optical properties of $(\mathrm{K}, \mathrm{Na}) \mathrm{NbO} 3$ nanoparticles synthesized by a modified sol-gel method using starch media," Adv. Powder Technol., vol. 26, no. 1, pp. 113-118, Jan. 2015. https://doi.org/10.1016/j.apt.2014.08.013

[3] T. R. Shrout and S. J. Zhang, "Lead-free piezoelectric ceramics: Alternatives for PZT?," J. Electroceramics, vol. 19, no. 1, pp. 113-126, Sep. 2007.

https://doi.org/10.1007/s10832-007-9047-0

[4] A. D. Woolf, R. Goldman, and D. C. Bellinger, "Update on the Clinical Management of Childhood Lead Poisoning," Pediatr. Clin. North Am., vol. 54, no. 2, pp. 271-294, Apr. 2007.

https://doi.org/10.1016/j.pcl.2007.01.008

[5] M. D. Maeder, D. Damjanovic, and N. Setter, "Lead Free Piezoelectric Materials," $J$. Electroceramics, vol. 13, no. 1-3, pp. 385392, Jul. 2004. https://doi.org/10.1007/s10832-004-5130-y

[6] F. Rubio-Marcos, P. Marchet, T. MerleMéjean, and J. F. Fernandez, "Role of sintering time, crystalline phases and symmetry in the piezoelectric properties of lead-free KNN-modified ceramics," Mater. Chem. Phys., vol. 123, no. 1, pp. 91-97, Sep. 2010.

https://doi.org/10.1016/j.matchemphys.2010.0 3.065

[7] H.-C. Thong, C. Zhao, Z.-X. Zhu, X. Chen, J.F. Li, and K. Wang, "The impact of chemical heterogeneity in lead-free $(\mathrm{K}, \mathrm{Na}) \mathrm{NbO} 3$ piezoelectric perovskite: Ferroelectric phase coexistence," Acta Mater., vol. 166, pp. 551559, Mar. 2019.

https://doi.org/10.1016/j.actamat.2019.01.012

[8] J.-F. Li, K. Wang, B.-P. Zhang, and L.-M. Zhang, "Ferroelectric and Piezoelectric Properties of Fine-Grained Na0.5K0.5NbO3 Lead-Free Piezoelectric Ceramics Prepared by Spark Plasma Sintering," J. Am. Ceram. Soc., vol. 89, no. 2, pp. 706-709, Feb. 2006. https://doi.org/10.1111/j.1551-

2916.2005.00743.x

[9] R. E. JAEGER and L. EGERTON, "Hot Pressing of Potassium-Sodium Niobates," $J$. Am. Ceram. Soc., vol. 45, no. 5, pp. 209-213, May 1962. https://doi.org/10.1111/j.11512916.1962.tb11127.x

[10] E. D. Politova et al., "Processing and characterization of lead-free ceramics on the base of sodium-potassium niobate," J. $A d v$. Dielectr., vol. 08, no. 01, p. 1850004, Feb. 2018.

https://doi.org/10.1142/S2010135X18500042

[11] S.-H. Hong and D.-Y. Kim, "Effect of Liquid Content on the Abnormal Grain Growth of Alumina," J. Am. Ceram. Soc., vol. 84, no. 7, pp. 1597-1600, Dec. 2004.

https://doi.org/10.1111/j.11512916.2001.tb00883.x

[12] B. Chen et al., "High-efficiency synthesis of high-performance K0.5Na0.5NbO3 ceramics," Powder Technol., vol. 346, pp. 248-255, Mar. 2019.

https://doi.org/10.1016/j.powtec.2019.01.039

[13] C. Frances, N. Le Bolay, K. Belaroui, and M. N. Pons, "Particle morphology of ground gibbsite in different grinding environments," Int. J. Miner. Process., vol. 61, no. 1, pp. 4156, Jan. 2001. https://doi.org/10.1016/S03017516(00)00025-9

[14] I.-W. Chen and R. Riedel, Ceramics Science and Technology. Weinheim, Germany: WileyVCH Verlag GmbH \& Co. KGaA, 2013. https://doi.org/10.1002/9783527631940

[15] I. Seo, C.-R. Lee, and J.-K. Kim, "Zr doping effect with low-cost solid-state reaction method to synthesize submicron $\mathrm{Li} 4 \mathrm{Ti} 5 \mathrm{O}$ 
12 anode material," J. Phys. Chem. Solids, vol. 108, pp. 25-29, Sep. 2017. https://doi.org/10.1016/j.jpcs.2017.04.011

[16] N. Chaiyo, B. Boonchom, and N. Vittayakorn, "Solid-state reaction synthesis of sodium niobate (NaNbO3) powder at low temperature," J. Mater. Sci., vol. 45, no. 6, pp. 1443-1447, Mar. 2010. https://doi.org/10.1007/s10853-009-4098-z

[17] A. Kamal, M. A. Rafiq, M. N. Rafiq, M. Usman, M. Waqar, and M. S. Anwar, "Structural and impedance spectroscopic studies of CuO-doped (K0.5Na0.5Nb0.995Mn0.005O3) lead-free piezoelectric ceramics," Appl. Phys. A, vol. 122, no. 12, p. 1037, Dec. 2016. https://doi.org/10.1007/s00339-016-0564-z

[18] R. Zuo, J. Rodel, R. Chen, and L. Li, "Sintering and Electrical Properties of LeadFree Na0.5K0.5NbO3 Piezoelectric Ceramics," J. Am. Ceram. Soc., vol. 89, no. 6, pp. 2010-2015, Jun. 2006.

https://doi.org/10.1111/j.1551

2916.2006.00991.x
[19] N. Kumada, T. Kyoda, Y. Yonesaki, T. Takei, and $\mathrm{N}$. Kinomura, "Preparation of KNbO3 by hydrothermal reaction," Mater. Res. Bull., vol. 42, no. 10, pp. 1856-1862, Oct. 2007. https://doi.org/10.1016/j.materresbull.2006.1 1.045

[20] F. Rubio-Marcos, J. J. Romero, and J. F. Fernandez, "Effect of the temperature on the synthesis of (K,Na)NbO3-modified nanoparticles by a solid state reaction route," J. Nanoparticle Res., vol. 12, no. 7, pp. 24952502, Sep. 2010.

https://doi.org/10.1007/s11051-009-9817-5

[21] C. Wattanawikkam, S. Chootin, and T. Bongkarn, "Crystal Structure, Microstructure, Dielectric and Piezoelectric Properties of Lead-Free KNN Ceramics Fabricated via Combustion Method," Ferroelectrics, vol. 473, no. 1, pp. 24-33, Dec. 2014.

https://doi.org/10.1080/00150193.2014.97443 8 